\title{
ALAN NORTHOVER
}

Alan Northover is registered for a PhD with the English Department at the University of Pretoria.

alan.northover@gmail.com

\begin{abstract}
The article aims to position J.M. Coetzee's The lives of animals within the animal rights debate and assess both his use of and his failure to use key philosophical texts in the animal rights movement. This task is complicated by his adoption of the controversial persona, Elizabeth Costello, who paradoxically uses reason to attack reason and continuously evokes the Holocaust analogy. The paper attempts to understand her views in relation to the leading animal rights philosophers, Peter Singer and Tom Regan, but also emphasizes her departure from their respectively utilitarian and rights-based positions, offsetting these against the positions of Mary Midgley, deep ecology, ecofeminism and the virtue ethics of Alasdair MacIntyre. The paper concludes with a consideration of views expressed by Coetzee in an interview and a speech.
\end{abstract}

Positioning J.M. Coetzee within the animal rights debate is a task complicated by his apparent adoption of the controversial figure of Elizabeth Costello as his persona. Her apparently paradoxical rejection of rationality in favour of the sympathetic imagination and her sustained analogy between animal exploitation and the Holocaust in The lives of animals are especially problematic. Indeed, some critics (Kunkel 1999, Singer 1999:91 and Webb 1999) ${ }^{1}$ are unwilling to identify her views with those of Coetzee and believe that he uses the fictional mode of the philosophical dialogue in order to express more extreme views than he himself would be prepared to admit to. However, I will argue that her views are, in fact, not that extreme in relation to the work of the leading animal rights philosophers and that they can be defended

\footnotetext{
${ }^{1}$ Since the reviews of Kunkel and Webb are web pages, page references cannot be provided.
} 
rationally, despite the fact that she seems excessively hostile towards the philosophical tradition of rationality and makes no attempt to make use of the arguments and moral authority of the pro-animal philosophers. Furthermore, it will be argued that even though Coetzee maintains an ironic distance between himself and his persona Elizabeth Costello, even though she is far more outspoken and blatant than Coetzee when making public statements on important issues, and despite the numerous critics cautioning against attempts to ascertain Coetzee's own views on animal rights, his views do seem to coincide quite closely with those of Costello. The views expressed by Coetzee in an interview in 2003 and in a speech he wrote for the opening of an art exhibition in Sydney in 2007 will be provided as evidence for this. In exploring our treatment of nonhuman animals, Coetzee goes to the heart of what it means to be human, critiquing our identity as the rational animal.

In order to position Costello and Coetzee within the animal rights debate, it will be necessary to consider the arguments and approaches of the leading animal rights and pro-animal philosophers whose influential works, namely Peter Singer's Animal liberation and Tom Regan’s Animal rights, Coetzee does not explicitly acknowledge in Lives, although he does refer to other works by them. Peter Singer's utilitarian and Tom Regan’s rights-based approaches to animal rights will initially be examined in relation to Lives. This will be followed by an exploration of approaches that share with Coetzee and Costello a rejection of appeals to ethical principles and a preference for moral intuitions or sentiments, namely the approaches of Mary Midgley and of ecofeminism. The apparent inadequacies of the utilitarian and rights-based approaches will necessitate an examination of one of the other major modern ethical 
schools of thought, namely virtue ethics, represented in this paper by Alasdair MacIntyre. I will argue that MacIntyre's controversial work, After virtue: a study in moral theory (1981) helps to explain Coetzee’s rejection of Enlightenment rationalism and its rights-based and utilitarian philosophies. Finally, I will ask why Coetzee criticises deep ecology ${ }^{2}$ and fails to avail himself of the considerable environmental arguments that have been raised in opposition to animal exploitation.

Peter Singer is not referred to in the text of Lives, but has an essay in the "Reflections" section of Lives and is the co-editor, with Tom Regan, of a collection of essays on animal ethics that is frequently cited in the footnotes of the novel. Singer's Animal liberation (1975) has been called "the Bible of animal liberation" and if one reads Lives after having read this seminal work in the animal liberation movement, one will see that Costello’s views are neither extreme nor idiosyncratic, but rather are shared by animal activists throughout the world. Indeed, the profound influence of Animal liberation can be perceived throughout Lives, although Coetzee does not merely parrot Singer's ideas but reworks them for his own purposes.

For instance, Costello's attack on the rationalism of the western philosophical tradition in the first part of Lives strongly echoes Singer's criticism of the same tradition for what he sees as "speciesism” - a term coined by Richard Ryder but popularized by Peter Singer - and the misuse of reason to justify the exploitation of

\footnotetext{
${ }^{2}$ Deep ecology is an eco-centric intellectual movement opposed to the anthropocentricism and instrumentalism inherent in modern western society and to industrialism's exploitative and destructive relation to nature. It rejects as a myth the idea of the autonomous, abstract individual separate from nature as a basis of ethics and asserts instead that humans are embedded and enmeshed in complex relationships with nature. Deep ecology also rejects shallow ecology's view that nature may be used sustainably as a source of renewable resources for human ends.
} 
animals. Yet, whereas Singer insists on using reason to convince people of the wrongness of speciesism, Costello appears, controversially, to reject reason, relying instead on the sympathetic imagination. She explicitly rejects philosophical discourse even though she simultaneously expresses her need for it:

"I want to find a way of speaking to fellow human beings that will be cool rather than heated, philosophical rather than polemical ... . Such a language is available to me, I know. It is the language of Aristotle and Porphyry, of Augustine and Aquinas, of Descartes and Bentham, of, in our day, Mary Midgley and Tom Regan. It is a philosophical language ... . I could fall back on that language, as I have said, in the unoriginal, secondhand manner which is the best I can manage... . [However, b] oth reason and seven decades of life experiences tell me that reason is neither the being of the universe nor the being of God .... . And if this is so, if that is what I believe, then why should I bow to reason this afternoon and content myself with embroidering on the discourse of the old philosophers?" (Coetzee 1999: 22-23)

Costello's inconsistent use of the philosophical and argumentative mode - her use of reason to attack reason - has been much criticized both within the novel, not least by her daughter-in-law, Norma, and by reviewers and critics of the novel, most notably by Peter Singer in an essay attached to the "Reflections" section of Lives. Coetzee pre-empts some of these criticisms in the person of Elaine Marx, who addresses Costello after her talk on "The poets and the animals":

"In your lecture [yesterday] you argued that various criteria - Does this creature have reason? Does this creature have speech? - have been used in bad faith to justify distinctions that have no real basis, between Homo and other primates, for example, and thus to justify exploitation.

"Yet the very fact that you can be arguing against this reasoning, exposing its falsity, means that you put a certain faith in the power of reason, of true reason as opposed to false reason.” (Coetzee 1999: 55)

While Costello's inconsistency in her use of reason may well be criticized, her rejection of rationality as a criterion justifying the unequal treatment of animals is 
perfectly justifiable and, indeed, is shared by Peter Singer. Significantly, Elaine Marx's words also echo very closely those of Jeremy Bentham, Peter Singer's philosophical father, so to speak, whom Singer quotes when criticizing the criteria people use to justify, or rationalize, their exploitation of animals: “[t]he question is not, Can they reason? nor Can they talk? but Can they suffer?” (Singer 2002: 8).

Furthermore, Costello does not use the term "speciesism” at any stage, although it is implicit in much of what she says, most clearly when she asserts, during the debate with O’Hearne, that:

"To me, a philosopher who says that the distinction between a human and nonhuman depends on whether you have a white or black skin, and a philosopher who says that the distinction between human and nonhuman depends on whether or not you know the difference between a subject and a predicate, are more alike than they are unlike.” (Coetzee 1999: 66)

Costello is criticized by Norma and Abraham Stern, an elderly Jewish academic, for evoking the Holocaust analogy, in which she compares the suffering of animals on factory farms and in laboratories to the suffering of Jews in Nazi death camps. Coetzee pointedly chooses to expose her to such criticism, allowing those voices to be heard, rather than indicate that Peter Singer has also drawn that analogy in detail, in turn evoking the controversial words of Isaac Bashevis Singer's protagonist Herman Gombiner in "The letter writer": "In their behavior towards creatures, all men [are] Nazis” (Singer 2002: 83-84). Likewise, her comparison of animal exploitation with human slavery and speciesism with racism can also be found in Peter Singer's Liberation. 
Singer's position is a form of utilitarianism and is thus based on the greatest happiness principle. Hence, for Singer, the supreme ethical imperatives are to maximize pleasure and minimize suffering. In particular, he appeals to the principle of the equal consideration of interests, arguing that if any being can suffer (which is part of the meaning of sentience), then it has interests; and that justice demands that we consider equally the interests of every being affected by any particular action, the respective interests being weighed up in a utilitarian calculation (Singer 2002: 7-8). Singer argues that if we take seriously the interests of infants, madmen and the severely retarded (so-called marginal cases) then rationality cannot be a morally relevant criterion (Singer 2002: 16-19). Thus, it is mere prejudice, akin to racism, to exclude nonhuman animals from the moral community simply because they lack rational capacities. A case can be made that Costello, following Singer, does not attack reason per se, but rather its use as a criterion to exclude nonhuman animals from the moral community.

The question is why does Coetzee not permit Costello to make use of the arguments and authority of Peter Singer? An obvious reason would be the fact that Singer's position, being based on utilitarianism, is a form of the instrumentalist rationalism that Costello is at pains to reject, since the cruel efficiency of the modern factory farm is based precisely on this form of reason. Furthermore, from a utilitarian position, the suffering and death of the animal could be outweighed by the greater happiness of the numerous people who eat it, although Singer argues that the animal's interest in its own life outweighs the relatively trivial aesthetic interests of the people who gain pleasure from eating it. Also, from a utilitarian point of view individuals are 
replaceable, since it is the sum total of pleasure and pain of all those concerned that is important rather than individual pain and pleasure. Thus Singer argues for the alleviation of the suffering of animals rather than against killing them painlessly for food. Costello would certainly reject this way of thinking, since she values the embodied, individual existence of animals.

Moreover, Singer himself objects, in his essay in the "Reflections" section of Lives, to Costello’s position, arguing that “There’s a more radical egalitarianism about humans and animals running through her lecture than I would be prepared to defend” (Coetzee 1999: 86). Singer expresses doubt that Costello’s arguments are Coetzee’s arguments, as indeed he should:

“Coetzee’s fictional device enables him to distance himself from them. ... It's a marvellous device, really. Costello can blithely criticize the use of reason, or the need to have any clear principles or proscriptions, without Coetzee really committing himself to these claims.” (Coetzee 1999: 91)

In contrast to Peter Singer's utilitarian approach is the deontological approach of Tom Regan, put forward in The case for animal rights (1983). Deontology can be defined as "The ethical theory taking duty as the basis of morality; the view that some acts are morally obligatory regardless of their consequences ... deontological ethics can be contrasted with any sort of utilitarianism, which must always be teleological” (Flew 1979: 88-89). Tom Regan and Mary Midgley are mentioned by Costello in the text of Lives (Coetzee 1999: 22), in a passage quoted earlier in this article. However, Costello does not discuss their work in the body of the text, although she cites an essay by Midgley entitled "Persons and nonpersons” (Coetzee 1999: 61). She also frequently cites Animal rights and human obligations, the collection of animal-related 
literature co-edited by Peter Singer and Tom Regan, in the footnotes of Lives (as mentioned above).

Regan makes use of a vivid metaphor to explain the difference between the utilitarian and rights-based (or deontological) approaches. One should imagine individuals as receptacles and the pain and pleasure that they experience as the liquid content of the receptacles (Regan 2004: 205-06). Utilitarians would value the content of the receptacles, believing the receptacles themselves to be replaceable, whereas the deontologists would value the receptacles, namely, the individuals, themselves.

It is interesting, and possibly part of the reflexive play of the literature surrounding Lives, that in his essay in "Reflections," Peter Singer also uses an image of receptacles, a bottle of soy milk and a bottle of Kahlúa (a coffee liqueur made in Mexico), to explain the utilitarian position to his daughter, Naomi, arguing that some experiences, namely human ones (the Kahlúa), are more valuable than others (the animals, or soy milk). When Naomi tries to defend Costello's position, that killing a human cannot be worse than killing a bat, Singer argues:

"Yes it can. If I pour the rest of this soymilk down the sink, I've emptied the container; and if I do the same to that bottle of Kahlúa you and your friends are fond of drinking when we are out, I'd empty it too. But you'd care more about the loss of the Kahlúa. The value that is lost when something is emptied depends on what was there when it was full, and there is more to human existence than there is to bat existence.” (Singer 1999: 90)

Regan’s position, like Costello’s, is far more egalitarian than Singer's. For Regan, the rights of animals are based on a principle of justice grounded in the notion of inherent value. What gives animals - and Regan, for argument's sake, limits these to healthy mammals of one year and older - inherent value is that they meet the subject-of-a-life 
criterion which marks a morally relevant similarity (Regan 2004: 245). That is, Regan contends that the capacity for subjective experience is the basis of inherent value and that all creatures with this capacity deserve to be treated equally. Thus, for Regan (as for Singer), rationality is not a morally significant criterion, and it cannot therefore justify the unequal treatment of animals and the consequent exploitation of nonhuman animals by humans. He, too, mentions marginal cases of humans to justify equal treatment with nonhuman animals. Regan's rights-based position is a valuable complement to Singer's utilitarianism and rectifies the latter's devaluing of the individual animal's experience. Taken together, these two philosophical contributions help significantly to advance the struggle for animal liberation; yet Coetzee does not give them due acknowledgement, possibly so that he can advance his case for the sympathetic imagination instead. Yet Regan also mentions Nagel's bat and discusses the imagination argument (Regan 2004: 64-67), contending that it is possible to imagine oneself into the experience of an animal, which, presumably, would endorse Costello’s claims for the sympathetic imagination.

Nonetheless, Costello's suspicion of principles would dissuade her from invoking the authority of Regan, even though his position would seem to share so much with hers:

"I was hoping not to have to enunciate principles," his mother says. "If principles are what you want to take away from this talk, I would have to respond, open your heart and listen to what your heart says.” (Coetzee 1999: 37)

Costello also objects to treating nonhuman animals as equivalent to severely retarded human beings, although she is referring more specifically to behaviourist experiments 
that conclude that nonhuman animals are imbeciles. She contends that " $[\mathrm{i}] \mathrm{t}$ is the experiments themselves that are imbecile” (Coetzee 1999: 62).

A central weakness of Regan's position - and Singer's - is the fact that the principles they use to argue for animal rights, the deontological and utilitarian principles respectively, have been used by others for exactly the opposite purpose, namely to justify the exploitation of nonhuman animals. According to Kant, since nonhuman animals do not qualify as persons, that is, as autonomous rational wills, we have no direct duties to them. Thus we may treat animals merely as means to human ends, although we should not be cruel to them, lest we are thereby encouraged to become cruel towards humans too. Consequently, philosophical liberalism seems to provide an uncertain basis for animal rights, despite Singer and Regan's attempts to extend the moral community to include all sentient beings.

A powerful (and controversial) critique of the philosophical basis of liberalism and of the impoverished language of analytic philosophy can be found in Alasdair MacIntyre’s After virtue (first published in 1981), an important work of virtue ethics that Coetzee quotes and discusses in the essay "Taking offense" in his collection of essays on censorship, entitled Giving offense. After quoting from Virtue, Coetzee goes on to elaborate:

Another name for MacIntyre's emotivism, the doctrine that moral judgments have no basis save in emotional attitudes, that is, save in the emotional orientation of the subject toward the world, is perspectivism .... .

[Perspectivism] is also a common feature of post-liberal moral philosophy, with its deep suspicion of foundational principles and in particular the axioms of liberalism. (Coetzee 2006: 23) 
While Coetzee makes use of Virtue in relation to the issue of pornography, he also uses it as a more general critique of liberal ethics and Enlightenment rationalism. MacIntyre’s ideas are central to Costello’s argument in Lives, not only negatively in offering a profound critique of liberal rationalism, but also positively in offering an alternative to liberal ethics, namely a form of virtue ethics that makes ample use of (Aristotelian) aesthetic concepts.

The most obvious relevance of Virtue to the argument pursued by Costello and Coetzee in Lives is MacIntyre's argument that there is no rational way to choose between modern moral positions or principles, namely utilitarianism and deontology, and that there is therefore no rational basis for liberalism's claims to moral universality. This, of course, completely undermines Peter Singer's use of utilitarian principles and Tom Regan's use of a modified Kantian respect for persons in order to provide an ethical basis for animal rights, and can also help explain why Coetzee has Costello avoid using these philosophers in her own argument.

Virtue also provides constructive ideas with which Coetzee can work or, at least, with which he can sympathize. In Offense, he uses the Erasmian image of life as a drama:

Life, says Erasmus's Folly, is theater: we each have lines to say and a part to play. One kind of actor, recognising that he is in a play will go on playing nevertheless; another kind of actor, shocked to find he is participating in an illusion, will try to step off the stage and out of the play. The second actor is mistaken. For there is nothing outside the theater .... (Coetzee 2006: 15)

Coetzee's Erasmian (and Shakespearean) observation resonates strongly with a similar observation by MacIntyre: 
In life, as both Aristotle and Engels noted, we are always under certain constraints. We enter upon a stage which we did not design and we find ourselves part of an action that was not of our making. (MacIntyre 2007: 213)

This is part of MacIntyre's critique of the abstract and impoverished language of behaviourism and analytic philosophy, and their failure to provide an adequate discourse for understanding human action and meaning. In its place MacIntyre offers what is in his view a far richer and more complex, Aristotelian, teleological and poetic understanding of human life whereby individual lives gain meaning by being expressed in narratives, embedded in the context of a broader community, with a shared history and telos or purpose, and in which virtues and vices help or hinder the individual to achieve eudemonia (variously defined as "flourishing", "fortune" or “happiness”) (MacIntyre 2007: 148).

MacIntyre criticizes behaviourism, whose experiments on animals Costello calls “imbecile” (Coetzee 1999: 62), for taking “intention” out of behaviour and analytic, speech-act philosophy for taking action out of context. For MacIntyre, actions require intentions, contexts and histories, namely narratives (which can be classified under different genres) in order to be meaningful and intelligible. He is partly applying Aristotelian poetics, but to human life rather than merely to drama and poetry. He continues later, further developing the idea of life as a drama and a narrative:

A central thesis then begins to emerge: man is in his actions and practice, as well as in his fictions, essentially a story-telling animal. He is not essentially, but becomes through his history, a teller of stories that aspire to truth ... . We enter human society, that is, with one or more imputed characters - roles into which we have been drafted - and we have to learn what they are in order to be able to understand how others respond to us and how our responses to them are apt to be construed. (MacIntyre 2007: 216) 
All of this powerfully endorses Elizabeth Costello's poetic challenge to the philosophers in Lives and helps to illuminate her own use of narratives throughout Lives as an alternative mode to that of discursive philosophical argument. In particular, her critique of the Cartesian and Kantian idea of the disembodied intellect, summed up in the abstract idea of "personhood," is countered by the fully embodied and (socially and historically) embedded concept of "character." MacIntyre points out how the modern liberal individualist notion of disembodied personhood enables some modern Americans to evade responsibility for their enrichment at the expense of black slaves, and of young Germans likewise to evade responsibility for the Holocaust (MacIntyre 2007: 220-21), since they fail to acknowledge that their identity is at least partly constituted by their history and the narratives that make up their histories. Costello faces a similar difficulty in Lives when she tries to convince her audience that they are implicated in "an enterprise of degradation, cruelty, and killing which rivals anything that the Third Reich was capable of, indeed dwarfs it ... " (Coetzee 1999: 21).

Besides a critique of liberal rationalism and the provision of an alternative virtue ethics for human life in which poetic terms guarantee meaningfulness, MacIntyre's ideas help to provide a coherent framework for integrating other aspects of Lives. Not only is Virtue a work of philosophical revisionism often in literary terms, but it begins with the word "Imagine" (MacIntyre 1981: 1) and then proceeds to provide a narrative of a world in which science has become completely fragmented as a result of a historical catastrophe, thereafter proceeding to suggest a similar type of disruption and fragmentation has occurred in modern moral discourse and society. As in Lives, 
here the imagination is given precedence over discursive philosophical discourse. Furthermore, it is significant that MacIntyre repudiates the philosophical tradition (analytic philosophy) within which he was trained, since this is the same tradition that Costello repudiates in Lives, and from a similar position in which aesthetic concepts are central.

MacIntyre's approach can also help to illuminate Costello's tendency, in her “philosophical” lecture, to create narratives rather than merely discuss concepts in an abstract, discursive mode. It may help understand why Coetzee chooses a narrative mode for his own Tanner lectures (and others) where, traditionally, a more philosophical mode is expected. It illuminates Coetzee's operating within - but critically challenging - a tradition of academic discourse, since MacIntyre shows that individuals are always embedded in institutions, traditions, family relationships and histories (MacIntyre 2007: 222). MacIntyre’s approach may also explain why Costello finds herself alone, lonely and isolated, since she does not appear to fit easily into any of these traditions or institutions.

Again, it helps to remind the reader of Coetzee's (and Costello's) ethical seriousness; his concern for the question of what constitutes the good life for human beings, not only in relation to questions of fundamental moral principles but also in terms of a practical virtue ethics. Indeed, one of MacIntyre's main criticisms of the liberal ethic is that, unlike an Aristotelian ethic, it provides no clear idea of how one is to live a good or meaningful life. Virtue ethics may thus help to explain both Coetzee's rejection of utilitarian and Kantian arguments for animal rights and the reason he puts 
into Costello’s mouth to explain her vegetarianism, namely that “[i]t comes out of a desire to save my soul” (Coetzee 1999: 43).

MacIntyre explains the importance of sentiment - something with which the rationalism of the philosophical tradition is uncomfortable - in virtue ethics:

Virtues are dispositions not only to act in particular ways, but also to feel in particular ways. To act virtuously is not, as Kant was later to think, to act against inclination; it is to act from inclination formed by the cultivation of the virtues. Moral education is an "education sentimentale”. (MacIntyre 2007: 149)

Finally, MacIntyre's approach may also help to explain why Costello insists that animals, as embodied souls, can experience joy - "One name for the experience of full being is joy”( Coetzee 1999: 33) - since, if humans possess a telos and can experience flourishing, there is no reason why nonhuman animals cannot too. This may explain her positive emphasis on animal well-being, rather than merely dwelling negatively on the suffering of animals. She seems to be suggesting a broadening of the moral community to include nonhuman animals, a community in which both humans and nonhuman animals can flourish together.

Although Coetzee does not refer to Midgley’s Beast and man (first published in 1978), he mentions her in the text of Lives and cites her in the notes. Coetzee may have taken much from the approach that informs Midgley’s Beast and man. Like Costello, Mary Midgley is suspicious of appeals to fundamental moral principles as a basis for justifying the better treatment of animals. Like Costello, she prefers moral intuitions (or sentiment) to moral theories as a starting point for an ethics of animals. She would presumably agree with Hacking's conclusion that "we have to be Humean and 
first worry about how to enlarge our sympathies. Rights and utilities will fall into place much later” (Hacking 2000: 26).

Midgley's approach has a subtlety that undermines binary oppositions. Thus she would reject the simplistic opposition of reason and emotion, or of philosophy and poetry. The following quotation, which employs a striking image, illustrates her approach:

I want to get away from the essentially colonial picture (used by Blake) in which an imported governor, named Reason, imposes order on a chaotic tribe of Passions or Instincts. The colonial picture, which is Plato's, was handed down through the Stoics, Descartes and Spinoza, to Kant. (Midgley 2002: 250)

It is precisely this idea of reason that Costello attacks. However, it is a stereotyped idea of reason, in contrast to Midgley's more balanced treatment of reason and emotion, an approach which avoids the extremes of Kant's rationalized ethical system and Hume's irrational, emotivist ethics. Nonetheless, it is an influential idea of reason, which is perhaps why Coetzee has Costello attack it so vehemently.

Both Midgley and Costello attack the privileged position of an abstract idea of reason and of persons as disembodied intellects, as is evident in their notions of "embodied intellects" (Midgley 2002: xlii) and the "embodied soul” (Coetzee 1999: 33). However, whereas Costello appears rashly to dismiss reason, Midgley does not exile reason so much as dethrone it in order to make it equal to all the other constituents in a democratic body politic, including imagination, intuition and emotion. Nor does Midgley simply reverse the hierarchical privileging of reason above body or emotion but rather treats these as equals. Despite their different emphases on the importance 
of reason, however, both Midgley and Costello are highly critical of Enlightenment rationalism for its failure to see the continuity between humans and the rest of nature and for using reason to justify this separation.

Deep ecologists also reject Enlightenment rationalism, along with its utilitarian and rights-based philosophies. Deep ecologists argue that:

... the concept of the isolated, atomistic individual, which arises out of the anthropocentric traditions of Western philosophy, is false to the facts of all life's embeddedness in the larger life community. People are not independent bits of mind existing by themselves; they are enmeshed in networks of relationships that bind them both to their evolutionary past and to their ecological present. (Regan 2001: 20).

In Costello’s words:

"To thinking, cogitation, I oppose fullness, embodiedness, the sensation of being - not a consciousness of yourself as a kind of ghostly thinking machine thinking thoughts, but on the contrary the sensation - a heavily affective sensation - of being a body with limbs that have extension in space, of being alive to the world. This fullness contrasts starkly with Descartes' key state, which has an empty feel to it: the feel of a pea rattling around in a shell." (Coetzee 1999: 33)

Costello would agree with deep ecologists' rejection of the instrumentalist attitude towards nature, with their rejection of the concept of the atomistic individual and with their concern with what it means to be human. However, she criticizes, as "Platonic," the abstractness of their own ideas of nature, which leads them to devalue the individuality of each animal: "The irony is a terrible one. An ecological philosophy that tells us to live side by side with other creatures justifies itself by appealing to an idea, an idea of a higher order than any living creature” (Coetzee 1999: 54). Her discussion of the value of bat being shows why she would reject this devaluing of 
animal experience: “To be a living bat is to be full of being. ... One name for the experience of full being is joy" (Coetzee 1999: 33). She would agree, however, that individuals are embedded, but not completely submerged, in their environment.

The apparent inconsistency of Costello's views - she condemns the exploitation of animals (Coetzee 1999: 21) yet uses leather shoes and purse (Coetzee 1999: 43); she criticises deep ecology (Coetzee 1999: 61) yet seems to approve of the pro-hunting stance that some deep ecologists would endorse (Coetzee 1999: 52) - suggests that it will not be easy to position her ideologically. Nonetheless, Costello’s position has much affinity with ecofeminism, a form of feminism and virtue ethics that radically challenges the basis of liberalism, in particular the masculine myth of the isolated individual, and which deplores all forms of oppression and exploitation:

Ecofeminists maintain that the same ideology that sanctions oppression based on gender also sanctions oppression based on race, class, and physical abilities, among other things. Moreover, they believe that this same ideology sanctions the oppression of nature in general and of nonhuman animals in particular. (Regan 2001: 21)

Not surprisingly, ecofeminists, like Costello, tend to be vegetarians, since a meatbased diet is based on violence and the abuse of animals, an oppressive relationship that ecofeminists would oppose. Ecofeminism departs from deep ecology because it detects androcentricism and instrumentalism in this movement, particularly in the attitude to hunting of some of its proponents, which would seem to contradict deep ecology's rejection of instrumentalist rationalism, since nature (namely, the animal hunted in a natural setting) is for them a mere means to the end of self-discovery. 
Even Costello’s qualified endorsement of hunting and bullfighting should, however, be seen in relation to the bigger evil of factory farming. Concerning hunting and bullfighting, Costello says that:

"We call this primitivism. It is an attitude that is easy to criticize, to mock. It is deeply masculine, masculinist. Its ramifications into politics are to be mistrusted. But when all is said and done, there remains something attractive about it at an ethical level.” (Coetzee 1999: 52)

Her openness to bullfighting and hunting cautions against a too hasty positioning of Costello, no matter how closely aligned she may seem to be with any position, even that of ecofeminism. She is able to appreciate the concreteness of even a masculine virtue ethics in comparison to the abstracted nature of life in a modern industrialized society where consumers are totally disconnected from the source of their food, particularly from the routine and impersonal violence involved in mass meat production. Of course, there is considerable irony in Costello’s condoning (aspects of) a masculinist ideology, of which fascism is an extreme form, while condemning Nazism's mass murders, and in her failing to acknowledge that both primitivism and industrialized animal exploitation share the "philosophy" of "Might is right."

Costello's position in the animal rights debate can now be summed up. Her attempts to expose what she sees as the moral and logical bankruptcy of speciesism, in particular the illegitimate use of the criterion of rationality to exclude nonhuman animals from moral consideration, ally her with Singer. Costello's insistence on “embodiedness" shows the continuity between humans and nonhuman animals and aligns her not only with Mary Midgley, but also with Tom Regan and the ecologists. 
She shares with Regan a belief in the value of individual animal subjectivity and does not follow deep ecologists who value the environment above the individual interests of animals. Nonetheless, in her refusal to espouse principles, in her emphasis on animal joy and on sentiment and intuitions, indeed in her being embodied as an ageing woman and anti-establishment figure, Costello most closely resembles Midgley, although she does not appear to share her respect for reason. Finally, Costello seems closely aligned with ecofeminism and its form of virtue ethics. In the end, however, she cannot be comfortably placed within any single school of thought.

In demonstrating the closeness of Costello’s views on animal rights with the various philosophers, whose views converge despite differences in principles and approaches, and especially with Midgley, it has been shown how reasonable Costello’s position on this issue is, notwithstanding her inconsistencies and her attack on reason. It will be argued that Coetzee’s views coincide quite closely with Costello’s, despite his ironic distancing from his persona and despite her strident public statements that contrast so strikingly with Coetzee’s famous elusiveness.

The main evidence for this claim is an interview with Satya, a Danish animal advocacy journal, one of the two interviews to which Coetzee agreed when he visited Denmark to receive the Nobel Prize in 2003, and a speech written by Coetzee, but delivered by Hugo Weaving, entitled “A word from J.M. Coetzee,” at the opening of an art exhibition, Voiceless: I feel therefore I am, at the Sherman Galleries, 22 February 2007, in Sydney. ${ }^{3}$

\footnotetext{
${ }^{3}$ Since these are web pages, page references cannot be provided.
} 
In the interview, Coetzee was asked: "What is your relation to animal rights philosophy? In what way do you think fiction can contribute to the question?” He responded:

Strictly speaking, my interest is not in legal rights for animals but in a change of heart towards animals. The most important of all rights is the right to life, and I cannot foresee a day when domesticated animals will be granted that right in law. If you concede that the animal rights movement can never succeed in this primary goal, then it seems that the best we can achieve is to show to as many people as we can what the spiritual and psychic cost is of continuing to treat animals as we do, and thus perhaps to change their hearts.

This echoes Costello’s appeal to her audience to open their hearts to the suffering of animals and helps to explain her enigmatic answer to the question whether her vegetarianism is a result of moral conviction: “No, I don’t think so ... . It comes out of a desire to save my soul” (Coetzee 1999: 43).

In his speech at the art exhibition in Sydney, Coetzee shows a similar concern for humanity, for humaneness, perhaps the main concern of Costello too. He points out the culpability of all the people who maintain the animal exploitation industries and support them by buying their products, including the people who are sickened by the cruelty of the industry but try to avoid thinking about it and shield their children from the truth, "because as we all know children have tender hearts and are easily moved." Coetzee then explicitly evokes the Holocaust analogy, making the connection between our treatment of animals and the Nazis' treatment of the Jews. Thus both Costello and Coetzee refuse to base their opposition to animal exploitation on utilitarian or deontological principles, choosing instead to appeal to imaginative sympathy and sentiment. Both are concerned about the impact on our humanity of the 
systematic exploitation and abuse of animals in the post-industrial world and both evoke the Holocaust analogy. It is not surprising, therefore, that both are suspicious of Enlightenment, liberal ethics, and appear to endorse, instead, a form of virtue ethics - that of ecofeminism - in which the good life would preclude the exploitation of animals, thereby redefining what it means to be human.

\section{Works cited}

Coetzee, J.M. 2004. Animals, humans, cruelty and literature: a rare interview with J.M. Coetzee. Satya, 4 May.

http://www.satyamag.com/may04/index.html

(6 June 2006).

Coetzee, J.M. 2007. “A word from J.M. Coetzee.” Read by Hugo Weaving at the opening of an art exhibition entitled Voiceless: I feel therefore I am. Sydney: Sherman Galleries, 22 February.

http://www.voiceless.org.au/index.php?option=comcontent\&task=view\&id=410\&Ite $\operatorname{mid}=369$.

(6 March 2007)

Coetzee, J.M. 2006. Giving offense: essays on censorship. Chicago and London: University of Chicago Press, 1-33.

Coetzee, J.M. 1999. The lives of animals. Princeton: Princeton University Press, 1569.

Flew, A. (ed.) 1979. A dictionary of philosophy ( $2^{\text {nd }}$ ed.). London: Pan Books Ltd.

Hacking, I. 2000. Our fellow animals. The New York Review of Books, June 29, 2026.

Kunkel, B. 1999. Eat, drink and be chary. The Nation, July 5.

http://www.thenation.com/doc/19990705/kunkel

(24 June 2009)

MacIntyre, A. 2007. After virtue: a study in moral theory ( $3^{\text {rd }}$ ed.). London: Duckworth.

Midgley, M. 2002. Beast and man: the roots of human nature ( $3^{\text {rd }}$ ed.). London: Routledge. 
Regan, T. 2001. Defending animal rights. Urbana and Chicago: University of Illinois Press, 1-27.

Regan, T. 2004. The case for animal rights ( $3^{\text {rd }}$ ed.). Berkeley: University of California Press.

Regan, T. and Peter Singer (eds.). 1976. Animal rights and human obligations. Englewood Cliffs, N.J.: Prentice-Hall.

Singer, I.B. 1984. The letter writer. In: The Penguin collected stories of Isaac Bashevis Singer. Harmondsworth: Penguin Books Ltd., 250-276.

Singer, P. 2002. Animal liberation: a new ethics for our treatment of animals ( $3^{\text {rd }}$ ed.). New York: Harper Collins Publishers.

Singer, P. 1999. Reflections. In: Coetzee, J.M. The lives of animals. Princeton: Princeton University Press, 85-91.

Webb, S.H. 1999. The lives of animals - review. Christian Century, May 19.

http://findarticles.com/mi_m1058/is_16_116/ai_54898660/

(24 June 2009) 